Отримано: 29 серпня 2018 р.

Прорецензовано: 06 вересня 2018 р.

Прийнято до друку: 14 вересня 2018 р.

e-mail: lm_1980@ukr.net

DOI: $10.25264 / 2311-5149-2018-10(38)-25-29$
Лишенко М. О. Аудит асортименту як напрям підвищення ефективності маркетингової діяльності підприємства. Наукові записки Начіонального університету "Осmрозька академія». Серія «Економіка» : науковий журнал. Острог : Вид-во НаУОА, вересень 2018. № 10(38). С. 25-29.

доктор економічних наук, дочент, професор, завідувач кафедри статистики, АГД та маркетингу,

Сумський національний аграрний університет

\title{
АУДИТ АСОРТИМЕНТУ ЯК НАПРЯМ ПІДВИЩЕННЯ ЕФЕКТИВНОСТІ МАРКЕТИНГОВОЇ ДІЯЛЬНОСТІ ПІДПРИЕМСТВА
}

У роботі розглянуто питання вдосконалення асортиментної політики вітчизняних підприємств. Запропоновано варіанти вдосконалення товарного асортименту на підприємстві. Використано інструменти оцінювання та прогнозування асортименту на підприємстві, зокрема метод опитування, метод попарних коефіиієнтів. Зроблено оиінку шансів нового товару на ринковий успіх.

Ключові слова: маркетинговий аудит, маркетинг, маркетингова діяльність, асортимент, номенклатура.

Лышенко Маргарита Александровна,

доктор экономических наук, доиент, профессор, заведуюший кафедрой статистики, АХД и маркетинга,

Сумской национальный аграрный университет

\section{АУДИТ АССОРТИМЕНТА КАК НАПРАВЛЕНИЕ ПОВЫШЕНИЯ ЭФФЕКТИВНОСТИ МАРКЕТИНГОВОЙ ДЕЯТЕЛЬНОСТИ ПРЕДПРИЯТИЯ}

В работе рассмотрены вопросы совершенствования ассортиментной политики отечественных предприятий. Предложены варианты усовершенствования товарного ассортимента на предприятии. Использованы инструменты оценки и прогнозирования ассортимента на предприятии, в частности метод опроса, метод попарньх коэффициентов. Произведена оченка шансов нового товара на рыночный успех.

Ключевые слова: маркетинговый аудит, маркетинг, маркетинговая деятельность, ассортимент, номенклатура.

\section{Margarita Lyshenko,}

Doctor of Economics, associate professor, Professor, Head of the Department of Statistics, AGD and Marketing,

\author{
Sumy National Agrarian University
}

\section{AUDIT OF ASSORTMENT AS A GUIDE TO IMPROVING EFFICIENCY OF MARKETING ACTIVITY OF THE ENTERPRISE}

The paper considers the issues of improving the assortment policy of domestic enterprises. Different variants of the commodity assortment perfection at the enterprises are offered. The author uses a number of tools for estimating and forecasting the assortment at the enterprise, in particular survey method and method of pairwise coefficients. An estimation of the new product success chances at the market is made.

The significance of the problems associated with the formation of the optimal assortment policy by the enterprises of the dairy industry is compounded by the complexity, ambiguity and divergence of the concept of assortment, which stems from its characteristics in different directions, features, categories, as well as the discovery of a multitude of various factors that influence its formation and need proper management. Considering the economic content and the theoretical aspects of the "assortment policy" concept, we came to the conclusion that there interpretation of this term is ambiguous.

The complex nature of the assortment policy means that the system of measures and approaches to assortment management should be aimed at the formation of a competitive assortment model that would ensure stable positions of the company in the market. The essence, directions, tasks, principles of assortment policy and its place in the management system of the enterprise in our opinion facilitate a preliminary conclusion that assortment policy is one of the key areas of dairy industry enterprises management activity.

Key words: marketing audit, marketing, marketing activity, assortment, nomenclature.

Постановка проблеми. Асортиментна політика займає найважливіше місце в товарній політиці молокопереробного підприємства. Досконало сформований асортимент продукції дає можливість збільшити платоспроможних покупців і досягти головної мети підприємництва - одержання найбільшого прибутку від реалізації продукції. Різноманітність асортименту - це один із важливих складових товарної політики вітчизняних підприємств. Наявність різних асортиментних груп і своєчасне задоволення потреб населен- 
ня 3 наданням якісних послуг взаємопов'язані між собою, тому всі товаровиробники повинні правильно сформувати асортимент на номенклатуру товарів. Отже, вивчення проблеми щодо покращення шляхів і методів аудиту асортименту є актуальним і має практичну важливість дослідження.

Аналіз останніх досліджень і публікацій. Питання покращення маркетингової діяльності і, зокрема, аудит асортименту продукції досліджували вітчизняні та зарубіжні науковці: В. В. Базилєв, О. Ю. Біленький, О. М. Бурова, К. С. Думанська, Н. С. Косар, П. В. Кузнецов, Т. С. Мазепа, С. О. Малюк, О. М. Прядко, Р. С. Русин, І. О. Сінгаєвський, А. В. Троян, Р. М. Федоряк, В. В. Шарко, В. Г. Щербак. Водночас дослідження підтверджують необхідність додаткових наукових дослідження з зазначених питань.

Метою статті є пошук шляхів удосконалення управління товарним асортиментом на підприємстві, що сприятимуть підвищенню ефективності та конкурентоспроможності вітчизняних підприємств.

Виклад основного матеріалу. Економічна сутність проблеми аудиту асортиментної політики полягає в координації всіх видів діяльності підприємства, які направлені на формування асортименту на перспективу з урахуванням попиту на ринку та вимог споживачів. Формування й аудит асортименту та номенклатури - це постійний процес, який містить увесь життєвий цикл товару, від стадії задуму до стадії реалізації $[6$, с. 105].

3 урахуванням ситуації, що склалися в молокопереробній промисловості, і на основі узагальнення накопиченого досвіду в галузі формування й управління асортиментом, ми вважаємо за необхідне запропонувати використання в ТОВ «Молкомбінат» механізму формування асортименту на принципах маркетингу.

Важливе значення у створенні асортименту має постійне його оновлення та модифікація. Наприклад, виготовлення вже наявних товарів, але з новим пакуванням, так і розширення асортименту завдяки товарам аналогів або імітаторам. Товар можна розподілити на три рівні: товар за задумом (підприємство планує отримати максимальний прибуток від реалізації), товар у реальному виконанні (містить основні складові товару), товар з підкріпленням (надання додаткових послуг). Відносно 2-го рівня товару, а особливо це стосується якості продукції і врахування державних стандартів якості. В конкурентних ринкових умовах виробництво товару розміщене на третьому рівні, тобто товару з підкріпленням. Відповідно ТОВ «Молокозавод» має розглянути можливість продажу товару в кредит, і використовуючи власну логістичну мережу [3, с. 308].

Кінцевою метою прогнозування обсягів продажів промислово-торговельного підприємства є зниження комерційних ризиків, основними з яких є дефіцит чи надлишок запасів товарів, що спричиняє заморожування коштів. Крім того, отримані прогнозні значення обсягів продажів можуть бути використані в якості вхідних даних під час оптимізації закупівель.

У межах концепції алгоритму вибору методу прогнозу наявна на підприємстві статистична інформація щодо продажів слугує початковими даними, необхідними для створення прогнозу, та є джерелом його верифікації. Вибір методу прогнозування відбувається з доступних у банку методів (до якого можуть бути включені всі описані вище методи) за певним критерієм оптимальності. А у випадку неможливості вибору одного з методів, прогноз доцільно будувати кількома методами, з яких у майбутньому визначається найкращий на основі порівняння даних, отриманих у результаті моделювання, з реальними статистичними. Це дає змогу у процесі роботи накопичувати інформацію щодо похибок прогнозів, притаманних тим чи іншим методам, що дозволяє робити висновки щодо оптимальності й ефективності використання різноманітних методів прогнозування. Товарна номенклатура ТОВ «Молокозавод» - це систематизований перелік усіх асортиментних груп (груп однойменної продукції - за видами) і товарних одиниць (окремих товарів), які виготовляє підприємство. ТОВ «Молокозавод» виготовляє та фасує широкий спектр продукції, тому ми пропонуємо вдосконалення товарної номенклатури (рис. 1). Зокрема, введення у виробництво нового виду продукції для дітей, тобто молоко, сирки та кефір [5, с. 503].

Перелік характеристик для оцінки відповідності нового товару інтересам товаровиробника визначено експертним методом [1, с. 406]. Шляхом опитування було відібрано основні оцінювальні характеристики. Застосуємо метод попарних порівнянь для визначення вагомості характеристик. Отримані результати використаємо під час побудови таблиць для оцінки (таблиця 1). У клітинках із характеристиками в дужках наведено їх вагомості.

Оцінки поставлено, виходячи $з$ таких міркувань:

- розрахункова собівартість молока «Мамонтятко» 2,5\% фас. 0,5 л. 5,83 грн і відпускна ціна (з ПДВ) 6,68 грн забезпечують прибуток у 0,85 грн (рентабельність - 14,6\%), що є цілком задовільним; розрахункова собівартість кефіру 1\% «Дитячий» фас. 5,62 грн і відпускна ціна (з ПДВ) 6,44 грн забезпечують прибуток у 0,82 грн (рентабельність - 14,5\%), що є цілком задовільним; розрахункова собівартість сирка 0\% 100 г - 5,51 грн і відпускна ціна (з ПДВ) 6,27 грн забезпечують прибуток у 0,76 грн (рентабельність - 13,8\%), що є цілком задовільним;

- ці продукти є технологічними у виготовленні і не потребують додаткового обладнання чи додаткових технологічних операцій;

- якість, як бачимо з таблиці, є на достатньо високому рівні; 


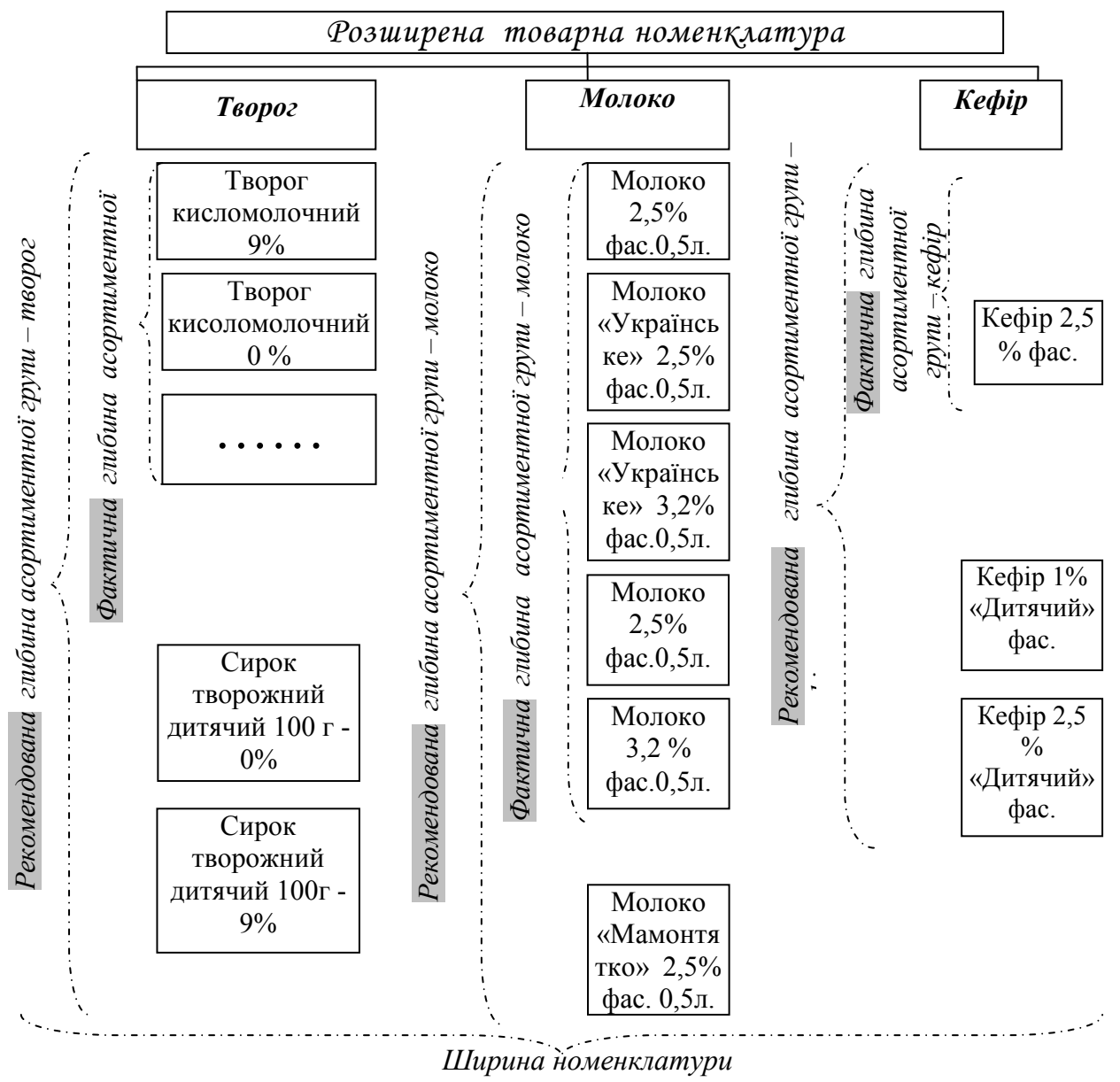

Рис. 1. Скоригована структура товарної номенклатури на 2019 рік

Аналіз відповідності товару-новинки потребам товаровиробника

\begin{tabular}{|l|c|c|c|c|c|}
\hline \multirow{2}{*}{\multicolumn{1}{|c|}{ Якісні характеристики товару }} & \multicolumn{4}{|c|}{ Оцінка за порядковою та бальною шкалами } \\
\cline { 2 - 6 } & $\begin{array}{c}\text { повна відпо- } \\
\text { відність (4) }\end{array}$ & $\begin{array}{l}\text { достатня від- } \\
\text { повідність (3) }\end{array}$ & $\begin{array}{c}\text { часткова від- } \\
\text { повідність (2) }\end{array}$ & $\begin{array}{c}\text { практично не } \\
\text { відповідас (1) }\end{array}$ & $\begin{array}{c}\text { повністю не } \\
\text { відповідас (0) }\end{array}$ \\
\hline Прибутковість (0,2) & $*$ & & & & \\
\hline Якість (0,13) & $*$ & & & & \\
\hline Технологічність виготовлення (0,13) & & $*$ & & & \\
\hline Сировинна забезпеченість (0,13) & $*$ & & & & \\
\hline Наявність споживачів (0,2) & & $*$ & & & \\
\hline Наявність каналів збуту (0,2) & & $*$ & & & \\
\hline
\end{tabular}

- невисока і нижча, порівняно з конкурентами, ціна, роблять товар привабливим для споживачів;

- аналіз показує, що для реалізації нових видів продукції цілком прийнятними є наявні канали збуту;

- сировину постачають із сільськогосподарських підприємств області та приватних домогосподарств за обумовленою ціною.

Тепер зробимо оцінку відповідності нового товару інтересам постачальників (таблиця 2).

Аналіз відповідності товару-новинки потребам постачальників

\begin{tabular}{|l|c|c|c|c|c|}
\hline \multirow{2}{*}{ Характеристика товару } & \multicolumn{5}{|c|}{ Оцінка за порядковою і бальною шкалою } \\
\cline { 2 - 6 } & $\begin{array}{c}\text { повна відпо- } \\
\text { відність (4) }\end{array}$ & $\begin{array}{c}\text { достатня від- } \\
\text { повідність (3) }\end{array}$ & $\begin{array}{c}\text { часткова від- } \\
\text { повідність (2) }\end{array}$ & $\begin{array}{c}\text { практично не } \\
\text { відповдає (1) }\end{array}$ & $\begin{array}{c}\text { повністю не } \\
\text { відповідає (0) }\end{array}$ \\
\hline Прибутковість $(0,4)$ & & $*$ & & & \\
\hline Стабільність замовлень (0,3) & $*$ & & & & \\
\hline Обсяги замовлень (0,3) & & $*$ & & & \\
\hline
\end{tabular}


Постачання сировини для продукції є вигідним. Обсяги замовлень є прийнятними, а стабільність повністю відповідає. Зробимо оцінку відповідності нового товару інтересам посередників (таблиця 3).

Аналіз відповідності товару-новинки потребам посередників

Таблиия 3

\begin{tabular}{|l|c|c|c|c|c|}
\hline \multirow{2}{*}{\multicolumn{1}{|c|}{ Характеристика товару }} & \multicolumn{5}{|c|}{ Оцінка за порядковою і бальною шкалами } \\
\cline { 2 - 6 } & $\begin{array}{c}\text { повна } \\
\text { відповід- } \\
\text { ність (4) }\end{array}$ & $\begin{array}{c}\text { достатня } \\
\text { відовідність } \\
\text { (3) }\end{array}$ & $\begin{array}{c}\text { часткова } \\
\text { відповідність } \\
\text { (2) }\end{array}$ & $\begin{array}{c}\text { практично не } \\
\text { відповідас (1) }\end{array}$ & $\begin{array}{c}\text { повністю не } \\
\text { відповідас (0) }\end{array}$ \\
\hline Стабільність постачання $(0,25)$ & $*$ & & & & \\
\hline Попит на продукцію $(0,35)$ & & $*$ & & & \\
\hline Прибутковість $(0,4)$ & & $*$ & & & \\
\hline
\end{tabular}

Визначимо вагомість кожного з економічних контрагентів (таблиця 4).

Оцінка вагомостей характеристик економічних контрагентів

\begin{tabular}{|l|l|c|c|c|c|c|c|c|}
\hline \multicolumn{1}{|c|}{ Фактори } & $\mathbf{1}$ & $\mathbf{2}$ & $\mathbf{3}$ & $\mathbf{4}$ & $\mathbf{5}$ & Сума & Вага \\
\hline 1 & Споживачі & & 0 & 1 & 1 & 1 & 3 & 0,3 \\
\hline 2 & Постачальники сировини & 1 & & 1 & 1 & 0 & 3 & 0,3 \\
\hline 3 & Посередники & 0 & 1 & 1 & 0 & & 2 & 0,2 \\
\hline & \multicolumn{2}{|l}{} & & & & & & 0,8 \\
\hline
\end{tabular}

Отже вагові характеристики економічних контрагентів відповідно такі: 0,$3 ; 0,3 ; 0,2$. Визначимо оцінки відповідності товару-новинки потребам усіх учасників ринку.

Товаровиробник:

$O_{m}=4 \cdot 0,2+4 \cdot 0,13+3 \cdot 0,13+0,4 \cdot 0,13+0,3 \cdot 0,2+3 \cdot 0,2=0,8+0,52+0,39+0,52+0,6+0,6=3,43$.

Постачальник:

$O_{n}=3 \cdot 0,4+4 \cdot 0,3+3 \cdot 0,3=1,2+1,2+0,9=3,3$.

Посередники:

$O_{\text {noc. }}=4 \cdot 0,25+3 \cdot 0,35+3 \cdot 0,4=1+1,05+1,2=3,25$.

Оскільки всі оцінки вищі, ніж 2,0 , то продовжуємо аналіз (якщо менше, то їх вилучаємо $з$ подальшого розгляду). Визначимо інтегральну оцінку відповідності товару-новинки потребам усіх вивчених учасників ринку:

$$
I=3,43 \cdot 0,3+3,3 \cdot 0,3+3,25 \cdot 0,2=1,029+0,99+0,65=2,669 .
$$

Для прийняття рішень щодо доцільності виведення нового товару на ринок використовується таблиця 5 .

Оцінка шансів нового товару на ринковий успіх

\begin{tabular}{|c|l|l|l|l|}
\hline $\begin{array}{c}\text { Оцінювальна } \\
\text { складова }\end{array}$ & $\begin{array}{l}\text { Відповідність потре- } \\
\text { бам учасників ринку }\end{array}$ & $\begin{array}{c}\text { Рівень можли- } \\
\text { вих витрат }\end{array}$ & $\begin{array}{c}\text { Рівень можливих } \\
\text { сукупних доходів }\end{array}$ & \multicolumn{1}{|c|}{ Розв'язання } \\
\hline $3,0<\mathrm{I} \leq 4$ & Повна & $\begin{array}{l}\text { Низька витратна } \\
\text { складова }\end{array}$ & Висока частка доходів & Є великі шанси на успіх \\
\hline $2,5<\mathrm{I} \leq 3,0$ & Достатньо повна & $\begin{array}{l}\text { Помірний рівень } \\
\text { витрат }\end{array}$ & Помірна частка & $\begin{array}{l}\text { Шанси на успіх } \epsilon, \text { але } \epsilon \text { потре- } \\
\text { ба в додатковому дослідженні } \\
\text { ринку }\end{array}$ \\
\hline $2,0 \leq \mathrm{I} \leq 2,5$ & Часткова & Високі витрати & Низька частка & $\begin{array}{l}\text { Дуже низькі шанси на успіх. } \\
\text { Виникає потреба поглибленого } \\
\text { маркетингового дослідження } \\
\text { ринку }\end{array}$ \\
\hline
\end{tabular}

Виходячи з таблиці 5, інтегральній оцінці 2,669 відповідає розв'язання щодо всіх шансів на успіх нових товарів - молока, сирків і кефіру для дітей.

Управління товарною лінією здійснюється з урахуванням довжини, глибини асортименту. Довжина товарної лінії ТОВ «Молзавод» залежить від стратегічних цілей підприємства. Цілями ТОВ «Молзавод» $€$ розширення меж ринку, тому має відносно довгі товарні лінії. ТОВ «Молзавод» має на меті частковий перехід нових підвидів товарів або їх модифікацій до більш дорогих цінових сегментів, тому необхідно витягувати товарні лінії вгору. Також довжина товарних ліній буде збільшена завдяки випуску нових товарів у межах наявного цінового діапазону (оновлення асортименту) [7, с. 400].

Висновки. Отже, можна зробити висновки, що аудит товарного асортименту й удосконалення маркетингової діяльності підприємства має базуватися на таких основних засадах: 
- процес формування товарного асортименту має враховувати технічні, технологічні можливості виробництва, доступну ресурсну базу (сировинне, фінансове, трудове забезпечення);

- аудит товарним асортиментом має базуватися на оцінюванні рівня задоволення клієнтів і споживачів створеної ціннісної пропозиції підприємства та передбачати можливість адаптації товарних пропозиції внаслідок динамічності ринкових умов;

- аудит товарного асортименту має бути безперервним, гармонізованим із конкурентною стратегією підприємства, враховувати вплив зовнішніх (ринкових) і внутрішніх (ресурсних) можливосте підприємства, різні стратегічні і функціональні аспекти оцінювання товарного портфеля;

- товарний асортимент має будуватися на принципах збалансованості, з урахуванням стадій життєвого циклу продуктових груп і окремих асортиментних позицій, з урахуванням особливостей управлінського впливу на зовнішні і внутрішні чинники функціонування і розвитку підприємства в короткостроковому і довгостроковому періодах;

- прийняття рішення слід здійснювати на основі якісної інформації - достовірної, повної, адекватної, об’єктивної й актуальної; особи, що приймають ці рішення, мають використовувати не тільки фактичні, а й прогнозні дані.

\section{Література:}

1. Базилєв В. В. Систематизація досліджень теорії та практики формування асортиментної політики. Економічна стратегія і перспективи розвитку сфери торгівлі та послуг. 2011. Вип. 1. С. 405-413.

2. Думанська К. С., Ющенко О. І. Формування асортименту продукції на підприємствах різних напрямів спеціалізації. Вісник Хмельницького національного університету. 2013. № 2. Т. 3. С. 138-141.

3. Косар Н. С., Кузьо Н. С. Маркетингова орієнтація діяльності молокопереробних підприємств. Вісник Національного університету «Львівська політехніка». Проблеми економіки та управління. 2013. C. 299-309.

4. Кузнецов П. В., Парфентенко И. А., Балагула Д. П. Маркетингове управління асортиментом продукції підприємства в умовах інформаційної економіки. Вісник економіки транспорту і промисловості. 2015 . № 49. C.199-204.

5. Лишенко М. О. Особливості застосування моделі оцінювання маркетингової діяльності підприємства. Актуальні проблеми соціально-економічних систем в умовах трансформаційної економіки: Збірник наукових статей за матеріалами III Всеукраӥнської науково-практичної конференції (13 - 14 квіт. 2017). Дніпро: Національна металургійна академія України, 2017. С. 502-510.

6. Прядко О. М. Управління торговим асортиментом в умовах національної конкурентної політики. Наук.вироб. журнал «БІЗНЕС - НАВІГАТОР», 2013. № 1. С.101-106.

7. Щербак В. Г., Перебийнос Р. В. Формування й реалізація стратегії управління асортиментною політикою підприємства. Економіка: проблеми теорії та практики: зб. наук. пр. Вип. 208. Т. 3. Д. : ДНУ, 2012. С. $399-404$. 